\title{
Bias problems in culture-independent analysis of environmental bacterial communities: a representative study on hydrocarbonoclastic bacteria
}

\author{
Husain Al-Awadhi, Narjis Dashti, Majida Khanafer, Dina Al-Mailem, Nidaa Ali and Samir Radwan*
}

\begin{abstract}
Culture-dependent methods for bacterial community analysis are currently considered obsolete; therefore, molecular techniques are usually used instead. The results of the current study on hydrocarbonoclastic bacteria in various oily habitats in Kuwait showed however, that the bacterial identities varied dramatically according to the analytical approach used. For six desert and six seawater samples used in this study, the culture-independent and culture-dependent techniques each led to a unique bacterial composition. Problems related to the culture-dependent technique are well known. The results of the current study highlighted bias problems other than those already recorded in the literature for the molecular approaches. Thus, for example, in contrast to the culture-dependent technique, the primers used in the molecular approach preferentially amplified the $16 \mathrm{~S}$ rDNAs of hydrocarbonoclastic bacteria in total genomic DNAs of all the studied environmental samples, and in addition, failed to reveal in any environmental sample members of the Actinobacteria. The primers used in the molecular approach also amplified certain "pure" 16S rDNAs, but failed to do so when these DNAs were in mixture. In view of these results, it is recommended that the two analytical approaches should be used simultaneously because their combined results would reflect the bacterial community composition more precisely than either of them can do alone.
\end{abstract}

\section{Introduction}

The end of the $19^{\text {th }}$ century witnessed the development of the well known and long adopted culture-dependent approach which is used for the study of the structure of the bacterial communities in various environments. This approach drove advances in microbiology, in spite of its well known, serious limitations (Amann et al. 1995; Jannasch \& Jones 1959), mainly related to the selectivity of the nutrient media and culture conditions which lead to favoring only a fraction of the inhabiting bacterial community. The major limitation of this classical technique is thus, that it dramatically underestimates the microbial numbers and composition in the samples under study. On the other hand, the major advantage of this approach over the modern molecular techniques lies

\footnotetext{
* Correspondence: samir.radwan@ku.edu.kw

Department of Biological Sciences, Faculty of Science, Kuwait University, P.O. Box 5969, Safat 13060, Kuwait
}

\section{Springer}

in that it provides the researcher with the microbial "material" that can be used in further studies.

Within the past few decades, molecular approaches have been developed (Head et al. 1998; Jannasch \& Jones 1959; Muyzer \& Smalla 1998) and used as alternative methods, neglecting in most studies the culture-depedent techniques, which are considered by most modern microbiologists as "obsolete". The molecular methods "provide a new insight into microbial diversity and allow a more rapid, high resolution description of microbial communities than that provided by the traditional approach of isolation of microorganisms" (Dahllöf et al. 2000). Molecular approaches which comprise among others the combination of DGGE fingerprinting with sequencing of $16 \mathrm{~S}$ rDNA bands to identify the species present in the environmental samples (Fuhrman \& Davies 1997; Nielsen et al. 1999; Rölleke et al. 1999), and correlating the banding patterns and band numbers on DGGE gels with environmental variables (El Fantroussi et al. 1999; Nübel et al. 
1999; Sievert et al. 1999; van Hannen et al. 1999a; van Hannen et al. 1999b) also have their limitations. Serious artifacts (Polz \& Cavanaugh 1998; Sipos et al. 2007) do arise viz preferential amplification of upcoming species, inadequate specificity of primers used for DNA amplification, production of single bands by multiple strains and others.

During two decades of research on microorganisms in pristine and oily Kuwaiti areas that were polluted via the greatest man-made oil-pollution catastrophy in association with the second Gulf War, 1990/1991 (Al-Awadhi et al. 2012), we consistently noticed that microbial identities determined by using culture-dependent methods for analysis were dramatically, sometimes completely different from those determined using molecular approaches. Here, we demonstrate this in a microbiological study on hydrocarbon-utilizing bacterial community structures in seawater and desert samples with over 20 years history of heavy oil-pollution. We concluded from the results that the simultaneous use of the traditional culturedependent methods, along with the modern molecular techniques is a must for obtaining precise findings from such studies.

\section{Materials and methods}

Oily and pristine seawater and desert soil samples were collected from various sites (Figure 1) along the Arabian Gulf coast, and from the desert of Kuwait, and processed the same day. As the culture-dependent method, we adopted the traditional dilution-plate method using a mineral medium with oil-vapor as the sole source of carbon and energy (Al-Awadhi et al. 2012). Representative colonies of oil vapor-utilizing bacteria were isolated and purified, their total DNA's were extracted, the $16 \mathrm{~S}$ rRNA genes were amplified using the universal primer pair GM5F and 907R, the amplicons were sequenced and the sequences compared with the nearest GenBank sequences (method details are available in reference (Al-Awadhi et al. 2012).

For the molecular analysis of the environmental samples, the total genomic DNAs in the latter were extracted using Rapid Water DNA Isolation Kit (MO-BIO, Carlsbad, CA) for seawater samples and Fast DNA Spin for Soil Kit (MP Biomedicals, LLC., France) for desert soil samples. The extracts were stored at $-80^{\circ} \mathrm{C}$ until used. The $16 \mathrm{~S}$ rRNA-genes in the purified extracts were amplified as described earlier (Al-Awadhi et al. 2012). The 16S rDNA amplicons were subjected to parallel DGGE using Dcode Universal Mutation Detection System (Bio-Rad, California, USA). The denaturant concentrations were $45-55 \%$ for seawater samples and $45-60 \%$ for desert soil samples. DGGE was processed with the constant voltage of $50 \mathrm{~V}$ at $60^{\circ} \mathrm{C}$ for $16 \mathrm{~h}$. Gels were stained with SYBR Green (Invitrogen, USA) in 1× TAE buffer
(1:100000) for $30 \mathrm{~min}$, and examined using a Dark Reader transilluminator (Clare Chemical Research, CO, USA). The bands were transformed into binary matrix; the presence of bands was given the weight of (1) and their absence (0). The binary matrix produced was analyzed using cluster analysis and dendrograms were plotted. For identification of individual bands; gel bands were excised, stored in $50 \mu \mathrm{l}$ molecular water (Sigma, UK) at $4^{\circ} \mathrm{C}$ overnight to elute the DNA, $1 \mu \mathrm{l}$ of the eluted DNA was amplified using the above primers, sequenced and the sequences were compared with the sequences in the GenBank database.

\section{Results}

The results of the culture-dependent analysis of the oilpolluted seawater and desert soil samples for the structure of their hydrocarbon-utilizing bacterial communities have been published before (Al-Awadhi et al. 2012), and are mentioned here only for comparison with the results of the current molecular analysis. The same environmental samples were used the same sampling day for total DNA extraction; the extracts were stored at $-80^{\circ} \mathrm{C}$ and used in the current study. Details of environmental conditions that were prevailing during sampling have been described elsewhere in details (Al-Awadhi et al. 2012).

The results of the DGGE analysis of partially amplified $16 \mathrm{~S}$ rDNA of the studied samples are presented in Figures 2 and 3 . For the purpose of comparison, we also co-analyzed nearby, visually pristine samples. The DGGE profiles of the various seawater samples (Figure 2) showed a high degree of similarity as far as the $16 \mathrm{~S}$ rDNA band numbers and migration patterns are concerned. This similarity was also valid for the profiles of the same sample irrespective of whether it was pristine or oil-polluted. In contrast, the DGGE profiles of the desert soil samples (Figure 3) exhibited dramatic variations, also depending on whether the sample was pristine or oil-polluted.

The 16S rDNA bands in Figures 2 and 3 were amplified, sequenced and the sequences were compared with the nearest sequences in the GenBank database. Like it was the case in many of our (and other) earlier reports, we failed to sequence many of the bands excised from the DGGE-gel. The results of this analysis (Tables 1 and 2) revealed only very little similarity but dramatic differences in comparison with the results previously obtained by the culture-dependent method (Al-Awadhi et al. 2012).

The slight similarity was expressed in the predominance of the phylum Gammaproteobacteria in seawater and its relative rarity in the terrestrial samples. Assuming that each DGGE band on the gel represents one single species, as commonly accepted, our results demonstrate that the species numbers determined by using the molecular analysis for all the environmental 


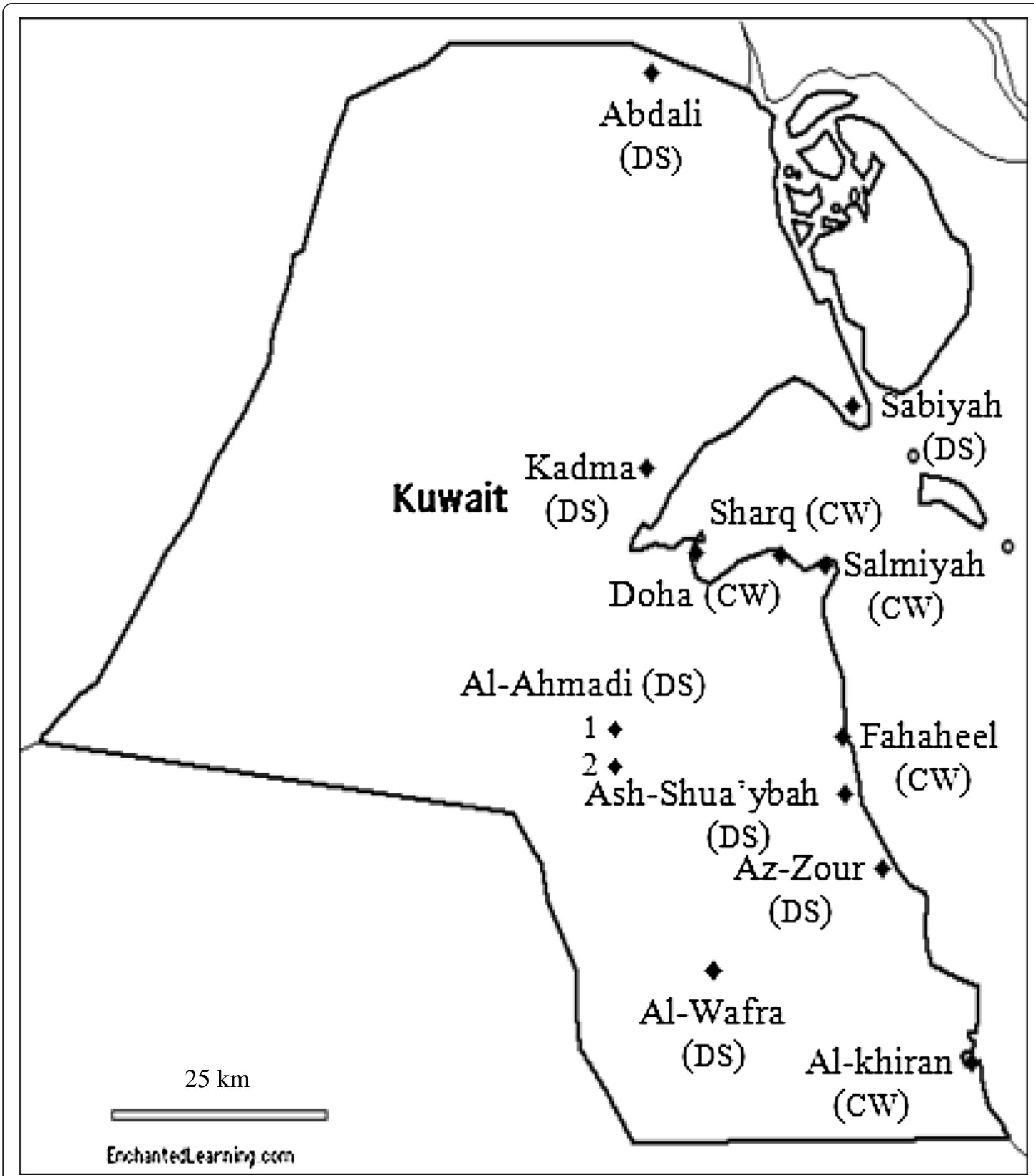

Figure 1 Kuwait map showing the coastal water (CW) and desert soil (DS) sampling sites.

samples were more than the numbers determined by using the culture-dependent method, and the differences were more pronounced for the desert than the seawater samples (Table 3). For the seawater samples, the differences ranged between about 1 and 4 fold, whereas for the desert samples, they ranged between about 1 and 12 fold more species counted by the molecular than by the culture-dependent methods.

In none of the six desert samples investigated could any single species be simultaneously recorded in the composition lists obtained by using the two techniques. Even the species belonging to the genera Bacillus and 


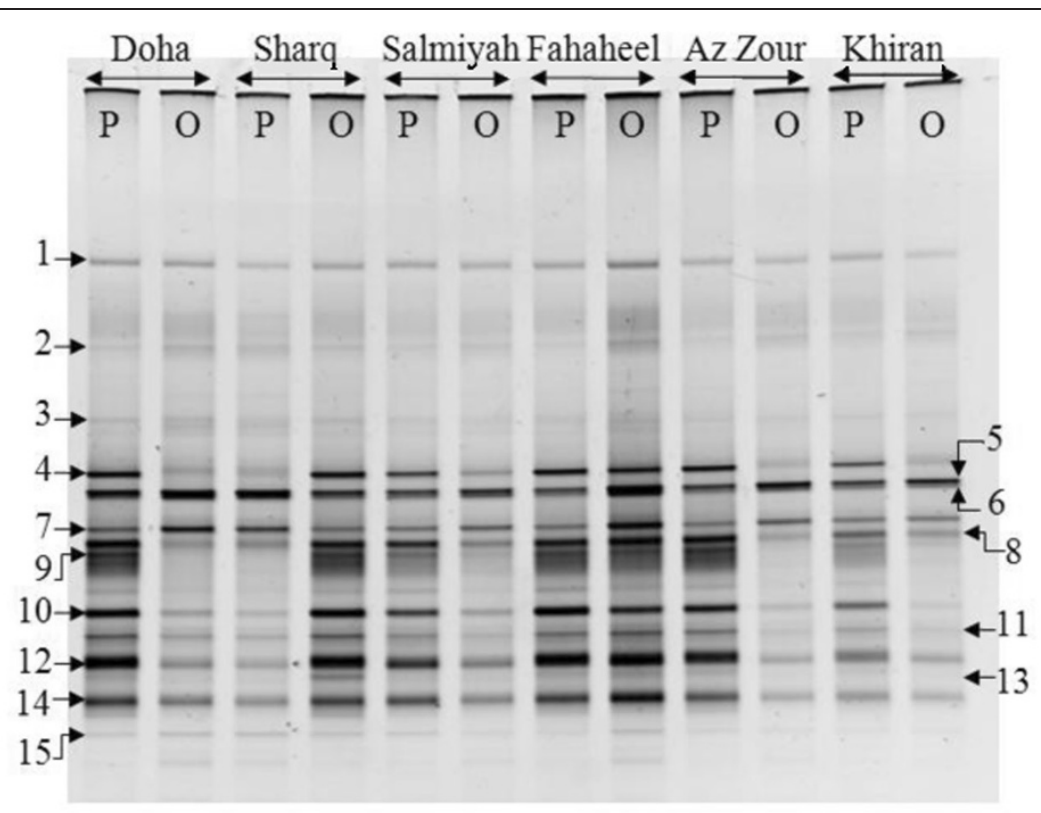

(a)

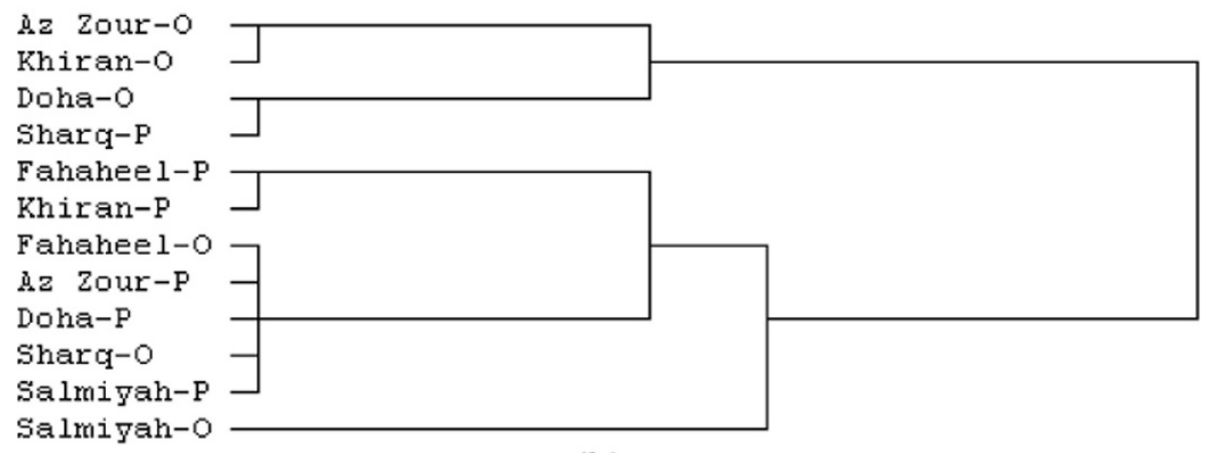

(b)

Figure 2 DGGE of $16 \mathrm{~S}$ rDNA amplicons in total DNA extracts from six pristine $(\mathrm{P})$ and nearby six oil-polluted $(0)$ seawater samples collected from the Arabian Gulf coast of Kuwait. (a) DGGE gel; in contrast to the cases of the "closed" desert samples (Figure 3), the DGGE bands of the "open" seawater samples were similar as far as the band numbers and patterns are concerned. The total numbers of the bands for all samples were not much higher than the total number of species recorded in each sample using culture-based analysis (Al-Awadhi et al. 2012). DNAs in individual bands were amplified, sequenced and the sequences were compared with those (cultured and uncultured) of the closest species in the GenBank (results in Table 1, which presents also information related to the sequencing). (b) Cluster analysis of DGGE-results using Euclidean distances.

Acinetobacter in Ash Shua'yba and Al-Wafra samples, respectively varied according to the analytical approach. Using the culture-dependent method (Al-Awadhi et al. 2012), we recorded $B$. infantis and $A$. septicus, whereas by the molecular analysis, we recorded $B$. niacini, $B$. selenatarsenatis and $A$. junii. Basically, the same observation, albeit at a slightly less pronounced level, could be made for the open seawater samples. In two samples; Sharq and Az Zour the bacterial species lists were totally different depending on the analytical technique. In the other remaining seawater samples, the molecular approach revealed only two species, Alteromonas macleodii and Pseudoalteromonas phenolica, which were also recorded by the culture-dependent method
(Al-Awadhi et al. 2012). The remaining species were totally different, as obvious in Table 3 . The analytical technique-dependent differences of the bacterial community composition are also quite obvious in the phylogenetic trees based on the bacteria analyzed by the molecular approach in Figures 4 \& 5 as compared with the corresponding trees based on bacteria analyzed by the traditional culture-deoendent method (Al-Awadhi et al. 2012).

For each of the 24 studied environmental samples, the bacterial community composition determined by using the culture-dependent method (Al-Awadhi et al. 2012) was dramatically, sometimes totally different from that determined by using the molecular approach. This 


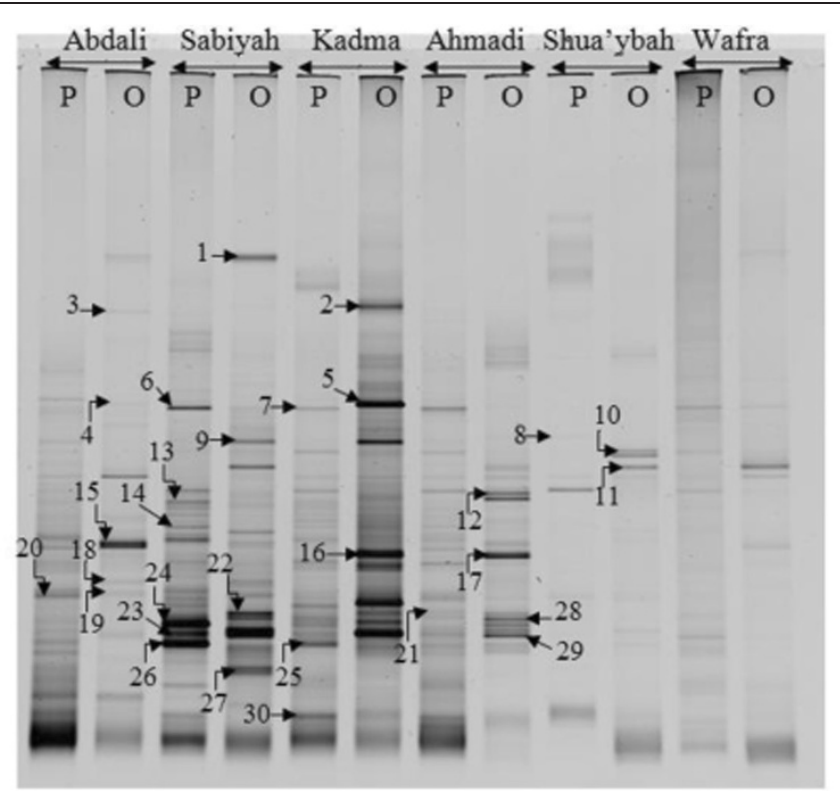

(a)

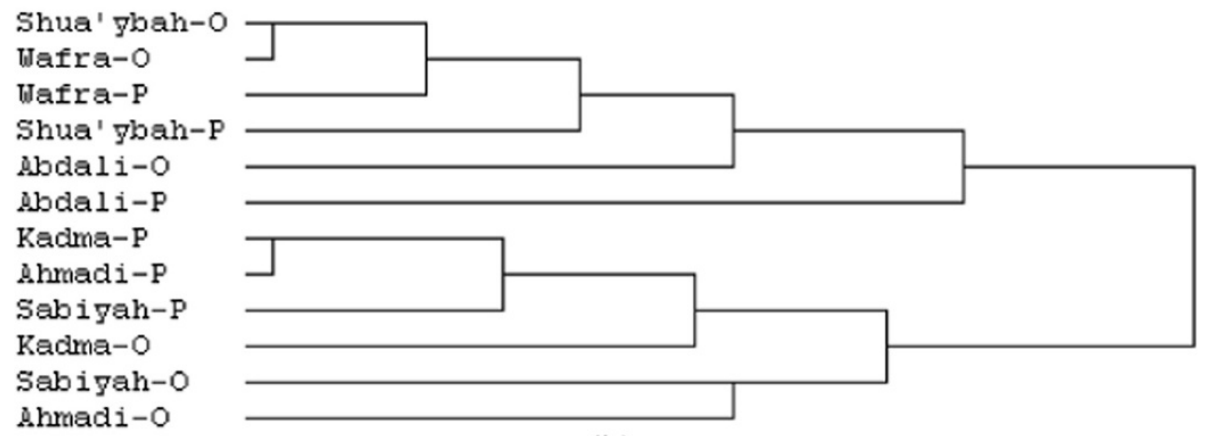

(b)

Figure 3 DGGE of $16 \mathrm{~S}$ rDNA amplicons in total DNA extracts from six pristine (P) and nearby six oil-polluted (O) soil samples collected from the Kuwaiti desert. (a) DGGE gel, the $16 \mathrm{~S}$ rDNA band numbers and patterns varied, not only according to the sampling sites, but also to whether the sample was pristine or oil-polluted. The bands were further processed as described in the legend to Figure 1, and the results are summarized in Table 2. (b) Cluster analysis of DGGE-results using Euclidean distances.

Table 1 Results of 16S rDNA sequencing of DGGE-bands of seawater samples in Figure 2

\begin{tabular}{|c|c|c|c|c|c|c|}
\hline $\begin{array}{c}\text { Band } \\
\text { no. }\end{array}$ & $\begin{array}{l}\text { Total } \\
\text { bases }\end{array}$ & Phylum & Nearest GenBank match & $\begin{array}{c}\text { Similarity } \\
(\%)\end{array}$ & $\begin{array}{c}\text { Bases } \\
\text { compared }\end{array}$ & $\begin{array}{c}\text { Accession } \\
\text { number }\end{array}$ \\
\hline 1 & 446 & a-Proteobacteria & Candidatus Pelagibacter ubique clone fosmid 01-003783 & 97 & $466 / 482$ & KC147468 \\
\hline 2 & 444 & Bacteroidetes & Uncultured Bacteroidetes* bacterium clone CB22B12 & 97 & $461 / 477$ & KC147469 \\
\hline 3 & 455 & Y-Proteobacteria & Alteromonas macleodii strain CAIM 891 & 96 & $494 / 513$ & KC147470 \\
\hline 4 & 402 & Y-Proteobacteria & Alteromonas macleodii strain CAIM 891 & 93 & $464 / 499$ & KC147471 \\
\hline 5 & 442 & Y-Proteobacteria & Thalassolituus oleivorans isolate SLHC162b & 96 & $490 / 513$ & KC147472 \\
\hline 6 & 450 & a-Proteobacteria & Phaeobacter caeruleus strain UDC410 & 98 & $468 / 477$ & KC147473 \\
\hline 7 & 447 & a-Proteobacteria & Phaeobacter caeruleus strain UDC410 & 98 & $465 / 474$ & KC147474 \\
\hline 8 & 455 & Y-Proteobacteria & Alteromonas macleodii strain SWDOH3 & 97 & $488 / 504$ & KC147475 \\
\hline 9 & 470 & y-Proteobacteria & Pseudoalteromonas phenolica & 97 & $504 / 521$ & KC147476 \\
\hline 10 & 438 & a-Proteobacteria & Thalassobius mediterraneus strain D6064 & 95 & $466 / 489$ & KC147477 \\
\hline
\end{tabular}


Table 1 Results of 16S rDNA sequencing of DGGE-bands of seawater samples in Figure 2 (Continued)

\begin{tabular}{lllllll}
\hline 11 & 438 & Y-Proteobacteria & Alteromonas macleodii strain D7081 & 94 & $487 / 517$ & KC147478 \\
12 & 405 & y-Proteobacteria & Alteromonas macleodii strain CAIM 891 & 94 & $452 / 481$ & KC147479 \\
13 & 430 & Y-Proteobacteria & Marinobacterium marisflavum strain IMCC4074 & 94 & $482 / 515$ & KC147480 \\
14 & 438 & Y-Proteobacteria & Marinobacterium marisflavum strain IMCC4074 & 96 & $485 / 506$ & KC147481 \\
15 & 440 & Y-Proteobacteria & Uncultured gammaproteobacterium clone OTU29 & 95 & $477 / 501$ & KC147482 \\
\hline
\end{tabular}

*Hydrocarbon-utilizers (Scherr et al. 2012; Jiménez et al. 2007).

implies that none of the two techniques can be used as a substitute of the other, since each of them favors bacterial taxa different from these favored by the other. Consequently, in order to limit the bias, both approaches should be adopted simultaneously, and the collective result would obviously reflect the "real bacterial composition" more precisely than that obtained using either of them alone, even though the bias problems are still not rased.

To provide a further evidence for the validity of the latter conclusion, the contribution of both techniques to the

Table 2 Results of 16S rDNA sequencing of DGGE-bands of desert soil samples in Figure 3

\begin{tabular}{|c|c|c|c|c|c|c|}
\hline $\begin{array}{l}\text { Band } \\
\text { no. }\end{array}$ & $\begin{array}{l}\text { Total } \\
\text { bases }\end{array}$ & Phylum & Nearest GenBank match & $\begin{array}{c}\text { Similarity } \\
(\%)\end{array}$ & $\begin{array}{c}\text { Bases } \\
\text { compared }\end{array}$ & $\begin{array}{c}\text { Accession } \\
\text { number }\end{array}$ \\
\hline 1 & 462 & Flavobacteriia & Salinimicrobium xinjiangense strain $\mathrm{BH} 206$ & 98 & $486 / 498$ & KC147483 \\
\hline 2 & 493 & Sphingobacteriia & Sediminibacterium sp. nju-T3 & 99 & $494 / 495$ & KC147484 \\
\hline 3 & 423 & Sphingobacteriia & Segetibacter koreensis strain Gsoil 664 & 95 & $476 / 502$ & KC147485 \\
\hline 4 & 500 & $\beta$-proteobacteria & Ralstonia solanacearum strain in $4 s s 52$ & 100 & $500 / 500$ & KC147486 \\
\hline 5 & 512 & $\beta$-proteobacteria & Ralstonia solanacearum strain in $4 s s 52$ & 100 & $512 / 512$ & KC147487 \\
\hline 6 & 493 & $\beta$-proteobacteria & Naxibacter alkalitolerans strain A12 & 99 & $503 / 510$ & KC147488 \\
\hline 7 & 519 & y-Proteobacteria & Acinetobacter junii strain OVC9 & 100 & $519 / 519$ & KC147489 \\
\hline 8 & 502 & Synergistetes & Synergistaceae* bacterium enrichment culture clone B6_95 & 100 & $502 / 502$ & KC147490 \\
\hline 9 & 510 & y-Proteobacteria & Acinetobacter junii strain OVC9 & 100 & $510 / 510$ & KC147491 \\
\hline 10 & 469 & Y-Proteobacteria & Uncultured Chromatialest bacterium isolate DGGE gel band B16 & 98 & $491 / 502$ & KC147492 \\
\hline 11 & 468 & y-Proteobacteria & Uncultured Chromatiales bacterium isolate DGGE gel band B16 & 98 & $490 / 501$ & KC147493 \\
\hline 12 & 501 & Synergistetes & Synergistaceae bacterium enrichment culture clone B6_95 & 99 & $504 / 505$ & KC147494 \\
\hline 13 & 462 & Cytophagia & Pontibacter akesuensis strain AKS 1 & 96 & $503 / 523$ & KC147495 \\
\hline 14 & 447 & Cytophagia & Pontibacter xinjiangensis strain: NBRC 107674 & 95 & $498 / 523$ & KC147496 \\
\hline 15 & 376 & Firmicutes & Bacillales bacterium Mi4 & 91 & $457 / 503$ & KC147497 \\
\hline 16 & 421 & Firmicutes & Firmicutes bacterium enrichment culture clone BSK_60 & 95 & $465 / 487$ & KC147498 \\
\hline 17 & 463 & $\beta$-proteobacteria & Curvibacter delicatus strain: NBRC 14919 & 97 & $500 / 518$ & KC147499 \\
\hline 18 & 513 & Firmicutes & Planomicrobium glaciei strain L25 & 99 & $515 / 516$ & KC147500 \\
\hline 19 & 494 & Firmicutes & Planomicrobium alkanoclasticum strain QT3+ & 99 & $498 / 502$ & KC147501 \\
\hline 20 & 498 & Firmicutes & Bacillus niacini strain GYR1 & 99 & $502 / 506$ & KC147502 \\
\hline 21 & 480 & $\beta$-proteobacteria & Burkholderia oxyphila clone: pCR2.1:OX-01_rDNA\#7 & 97 & $499 / 512$ & KC147503 \\
\hline 22 & 425 & Firmicutes & Bacillus selenatarsenatis strain NBSL41 & 96 & $458 / 475$ & KC147504 \\
\hline 23 & 501 & Firmicutes & Planomicrobium glaciei strain GDM825 & 99 & $502 / 503$ & KC147505 \\
\hline 24 & 493 & Firmicutes & Planomicrobium okeanokoites & 99 & $494 / 495$ & KC147506 \\
\hline 25 & 475 & Firmicutes & Planomicrobium okeanokoites strain QL-25 & 98 & $486 / 494$ & KC147507 \\
\hline 26 & 514 & Firmicutes & Planomicrobium glaciei strain L25 & 99 & $516 / 517$ & KC147508 \\
\hline 27 & 427 & Firmicutes & Uncultured Geobacillus sp. clone SHBZ1548 & 94 & $484 / 513$ & KC147509 \\
\hline 28 & 464 & Firmicutes & Bacillus selenatarsenatis strain NBSL41 & 95 & $496 / 521$ & KC147510 \\
\hline 29 & 505 & Firmicutes & Bacillus selenatarsenatis strain NBSL41 & 99 & $506 / 507$ & KC147511 \\
\hline 30 & 475 & y-Proteobacteria & Halomonas xinjiangensis strain YIM 91125 & 97 & $502 / 518$ & KC147512 \\
\hline
\end{tabular}


Table 3 Comparison between the composition of hydrocarbon-utilizing bacterial communities in seawater and desert soil-samples determined by the culturebased method versus that determined by a modern molecular approach

\begin{tabular}{|c|c|c|c|}
\hline \multirow[t]{2}{*}{$\begin{array}{l}\text { Sampling } \\
\text { sites }\end{array}$} & $\begin{array}{l}\text { Culture-based analysis (using a mineral medium with oil vapor as sole source of carbon } \\
\text { and energy, detailed results in Al-Awadhi et al. 2012) }\end{array}$ & \multicolumn{2}{|r|}{ Combined DGGE and band amplification analysis } \\
\hline & $\begin{array}{l}\text { Total number Affiliated to the hydrocarbon-utilizing genera: } \\
\text { of species }\end{array}$ & $\begin{array}{l}\text { Total number of } \\
\text { DGGE bands }\end{array}$ & $\begin{array}{l}\text { Affiliated to the genera (hydrocarbon-utilizers are designated } \\
\text { with the pertinent reference numbers): }\end{array}$ \\
\hline
\end{tabular}

\begin{tabular}{lll}
\multicolumn{3}{c}{ of species } \\
\hline Seawater \\
Doha 17 & $\begin{array}{l}\text { Psychrobacter, Oceanobacillus, Vibrio, Agarivorans, Alteromonas, Marinobacter, } \\
\text { Stappia, Pseudoalteromonas, Microbacterium, Marinomonas, Nesiotobacter, } \\
\text { Mycobacterium }\end{array}$ \\
Sharq & 5 & Alcanivorax, Stappia, Thalassospira, Nitratireductor
\end{tabular}

Sharq 5 Alcanivorax, Stappia, Thalassospira, Nitratireductor

Salmiyah $15 \quad$ Alteromonas, Echinicola, Klebsiella, Alcanivorax, Marinomonas, Gordonia

Alteromonas, Echinicola, Klebsiella, Alcanivorax, Marinomonas, Gordonia,
Pseudomonas, Rhodococcus, Microbacterium, Vibrio, Marinobacter, Kocuria

Fahaheel 9 Pseudomonas, Dietzia, Shewanella, Arthrobacter, Pseudoalteromonas, Acinetobacter, Alteromonas

Az Zour 4 Alcanivorax, Cobetia, Pseudoalteromonas

Al Khiran 6

Alcanivorax, Alteromonas, Pseudoalteromonas, Cobetia

Desert soil

Al Abdali 7

Sabiyah 8

Kadma 4

Arthrobacter, Dietzia, Microbacterium, Streptomyces, Agrococcus

Microbacterium, Dietzia, Pseudomonas, Bordetella, Roseomonas,

30

36

Ahmadi 6 Cellulomonas, Pseudomonas, Arthrobacter, Sphingomonas

Ash $12 \quad$ Mycobacterium, Nocardia, Rhodococcus, Streptomyces, Bacillus

Al Wafra 8

Kocuria, Streptomyces, Agrobacterium, Acinetobacter, Pseudomonas, Brevundimonas, Sphingobium
18

15

47

Alteromonas, Candidatus', Marinobacterium, Phaeobacter, Thalassobius $^{2}$, Thalassolituus ${ }^{3}$

Alteromonas, Candidatus, Marinobacterium, Phaeobacter, Pseudoalteromonas, Thalassobius, Thalassolituus

Alteromonas, Candidatus, Marinobacterium, Phaeobacter, Pseudoalteromonas, Thalassobius, Thalassolituus

Alteromonas, Candidatus, Marinobacterium, Phaeobacter, Pseudoalteromonas, Thalassobius, Thalassolituus

Alteromonas, Candidatus, Marinobacterium, Phaeobacter, Thalassobius, Thalassolituus

Alteromonas, Candidatus, Marinobacterium, Phaeobacter*, Pseudoalteromonas, Thalassobius, Thalassolituus

Bacillus, Planomicrobium ${ }^{4}$, Ralstonia $^{5}$, Salinimicrobium ${ }^{6}$, Segetibacter ${ }^{7}$ Acinetobacter, Bacillus, Burkholderia ${ }^{8}$, Geobacillus ${ }^{9}$, Halomonas ${ }^{10}$, Naxibacter ${ }^{11}$, Planomicrobium, Ralstonia

Acinetobacter, Bacillus, Burkholderia, Curvibacter ${ }^{5}$, Sediminibacterium Halomonas, Naxibacter, Planomicrobium, Pontibacter ${ }^{12}$, Ralstonia

Segetibacter

30 Acinetobacter, Bacillus, Burkholderia, Curvibacter, Naxibacter,

Planomicrobium, Pontibacteter

17 Bacillus, Planomicrobium, Pontibacter

17 Acinetobacter, Bacillus, Halomonas, Naxibacter

*No references were found on the hydrocarbon-degradation potential of Sediminibacterium or Phaeobacter. The superscript numbers are the reference numbers in the list recording hydrocarbonoclastic activity among species belonging to the given genera (1, Prabagaran et al. 2007; 2, Teramoto et al. 2009; 3, Yakimov et al. 2004; 4, Yakimov et al. 2007; 5, Zhu et al. 2010; 6, Yergeau et al. 2012; 7, Larentis et al. 2009; 8; Morawski et al. 1997; 9, Arun et al. 2011; 10, Wang et al. 2007; 11, Kleinsteuber et al. 2006; 12, Wan et al. 2011).

Genera that were revealed by both approaches are in bold. 


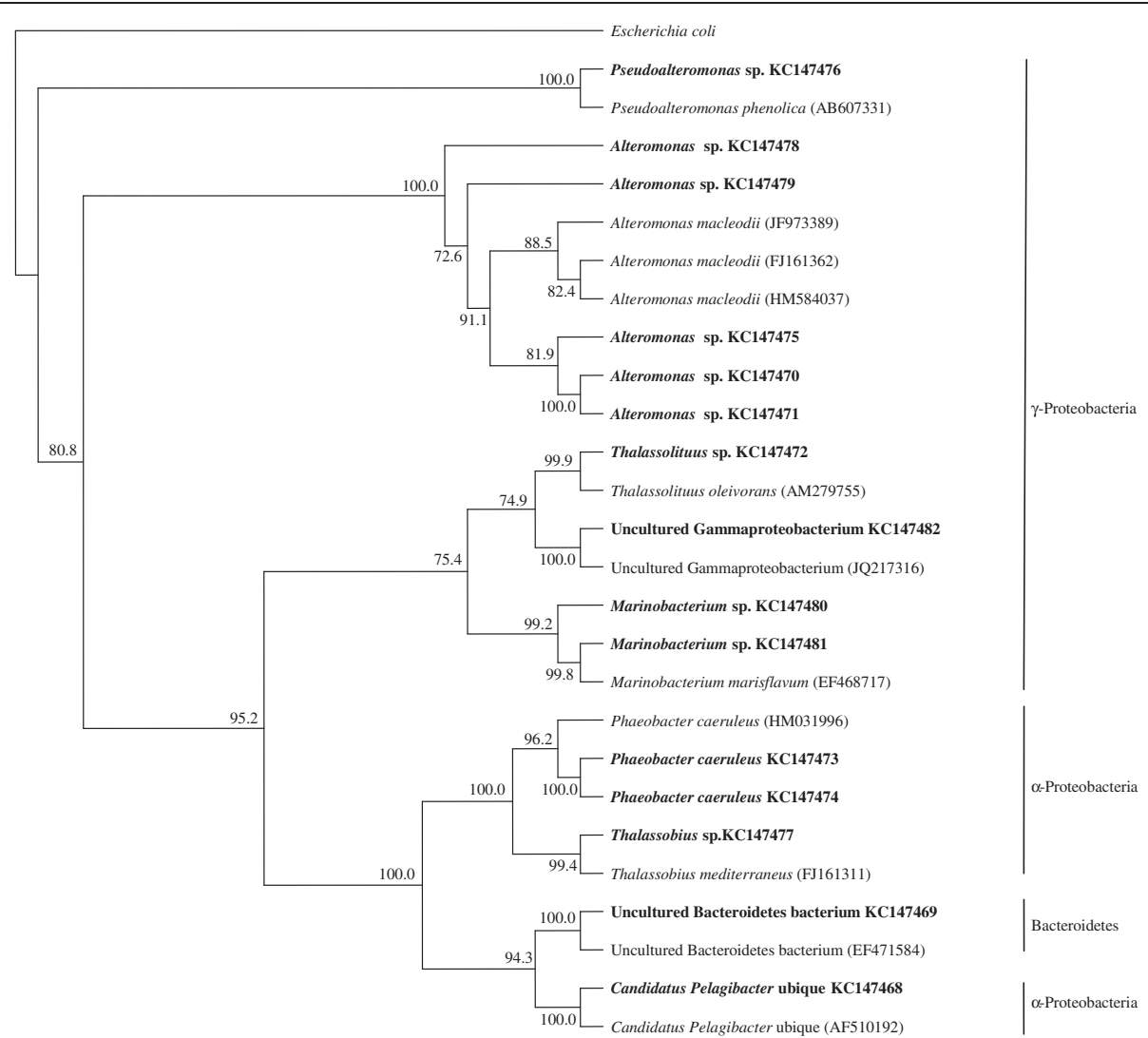

Figure 4 Phylogenatic tree of $16 \mathrm{~S}$ rRNA genes of bacteria from Kuwaiti oil polluted coastal water, as analyzed by the culture-independent method. Values shown in each node of the phylogenetic tree are bootstrap value; 2,000 bootstrap replicates were performed.

analysis of the group of the "obligate oil-degrading marine bacteria" in the seawater samples is highlighted. This is a new and ecophysiologically unusual group recently recognized and termed "the obligate hydrocarbonoclastic bacteria (OHCB)"; they repotedly play the major role in bioremediating oil in the marine ecosystem (Yakimov et al. 2007). The most common OHCB are species belonging to a few genera; Alcanivorax, Marinobacter, Thalassolituus, Cycloclasticus and Oleispira that occur in pristine seawater in minute numbers, but bloom immediately after oilpollution. Our results show that Alcanivorax described as the "paradigm" of the OHCB (Yakimov et al. 2007), and Marinobacter were recorded, respectively, in 4 and 2 of the studied seawater sites, but only by using the culturedependent analytical method (Al-Awadhi et al. 2012). The molecular approach we adopted failed to reveal any of the two OHCB genera in any of the six seawater samples. On the other hand, the genus Thalassolituus was recorded in all six sampling sites, but only when the molecular approach was adopted. By neither of the two techniques could Cycloclasticus and Oleispira be recorded in any of the six seawater samples. Probably, the two genera were not present in the studied samples. Interestingly however, using the molecular (but not the culture-dependent) approach, we recorded the former genus in biofilms on glass plates submerged in pristine and oily Gulf-water (AlBader et al. 2012).

\section{Discussion}

The DGGE profile similarities of the different seawater samples (Figure 1) should be expected, in view of that seawater in situ is an "open" environment in which the whole water body becomes mechanically mixed up to some extent. Remote samples would thus, show a degree of similarity in their microbial composition. Meanwhile, the DGGE dissimilarities of the different desert soil samples (Figure 2) may be explained on the basis that the processes regulating the bacterial species frequencies in various localities, the so-called patchiness operate at a very narrow, sometimes centimeter spacial scale (Duarte \& Vaqué 1992; Long \& Farooq 2001; Seuront et al. 2002; Seymour et al. 2000). Expectedly, this phenomenon should be more pronounced in the "closed", terrestrial than the "open", aquatic environments. The observed frequent occurrence of the Gammaproteobacteria in the Arabian Gulf water body has also often been recorded by earlier investigators (Al-Awadhi et al. 2012; Al-Sarawi et al. 2008) in the marine habitats. 


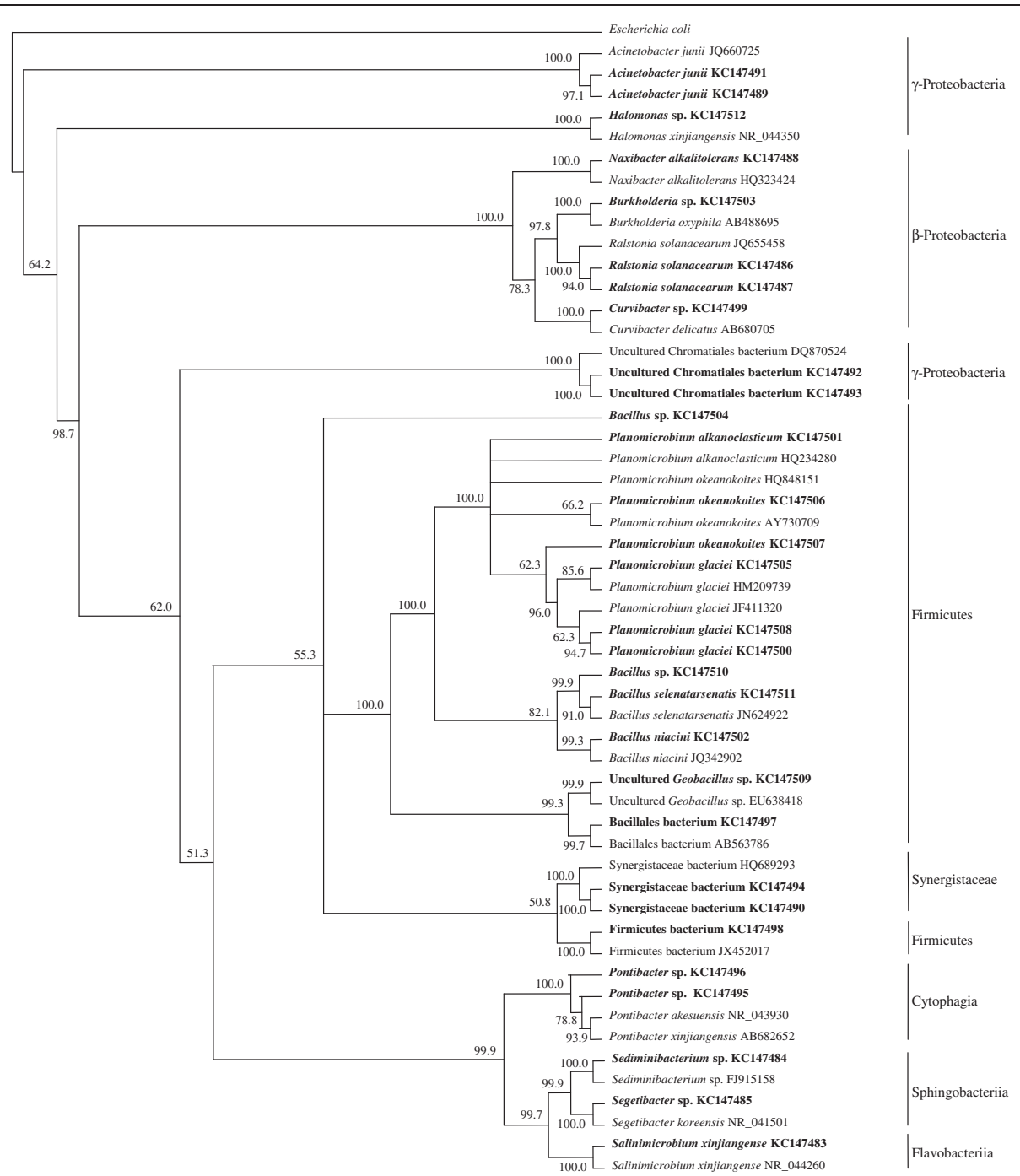

Figure 5 Phylogenatic tree of $16 \mathrm{~S}$ rRNA genes of bacteria from Kuwaiti oil polluted desert soil, as analyzed by the culture-independent method. Values shown in each node of the phylogenetic tree are bootstrap value; 2,000 bootstrap replicates were performed.

An important and well known advantage of the culture-dependent approach is that it routinely analyses specific groups of bacteria (in this study oil-utilizers) via the use of selective nutrient media. Since this is not the case with the molecular analysis, we had to compare our results with literature reports. The comparison confirmed that all the bacterial genera listed in Table 3, with the only exception of Sediminibacterium and Phaeobacter, comprised hydrocarbon-utilizing species (see pertinent reference numbers in Table 3). This result demonstrates a serious bias, namely that the used molecular approach preferentially amplified the $16 \mathrm{~S}$ rDNAs of hydrocarbon-utilizing bacteria in the total DNA extracts from the environmental samples and might have "neglected" others. Still another even more pronounced bias is that the molecular approach used did not reveal in any of the studied environmental samples any member of the phylum Actinobacteria. This was true although by using the culture-dependent method, many species belonging to this phylum were found (sometimes predominant) especially in the desert soil samples (Al-Awadhi et al. 2012). Obviously the technique successfully amplifies certain $16 \mathrm{~S}$ rDNA's only when in pure form, but not when mixed with others, as it is the case in the environmental samples. The molecular analysis of bacterial communities on biofilms that developed on glass plates submerged in pristine and oily seawater from the Arabian Gulf (samples similar to those used in this study) also did not reveal one single species belonging to the Actinobacteria (Al-Bader et al. 2012). The present state of knowledge about this subject in the literature is too limited to 
explain the reason for this latter bias of preferential amplification.

It should be expected that the molecular technique would reveal in every environmental sample most, if not all of the bacterial species that showed up in these samples using the culture-dependent method. Therefore, the most surprising result in our study was that the identities of the bacteria analyzed by both techniques for all the studied samples (and for samples analyzed earlier in our laboratory) were dramatically different. In this context, the assumption that each DGGE band represents one single species is not correct (Sekiguchi et al. 2001). It is established today that differential/preferential amplification of 16S rRNA-genes in environmental samples usually leads to serious bias regarding the actual composition of the bacterial communities (Polz \& Cavanaugh 1998; Sipos et al. 2007). Again the results of the current study demonstrate that the technique-dependent differences in community composition are so dramatic that both techniques should necessarily complete, and not just substitute one another in every study. This is true although both approaches are associated with own bias problems. Based on our results, the molecular approach does not seem to reveal numerically much more bacterial species (even though it reveals different rather than the same species) in the environmental samples than the culture-dependent approach, as commonly believed, so far. As shown above, the differences were in all the studied samples only between about 1 and 12 fold, in favor of the molecular approach. This may appear to contradict the well known fact that direct microscopic counts give frequently up to $10^{4}$ fold more bacterial cell numbers than those counted by the culture-dependent method. This implies that the cells counted microscopically are most probably members of "strains" or "varieties" belonging to a limited number of species, rather than to different species as frequently misunderstood.

As already mentioned, modern microbiologists tend to consider the traditional culture-dependent methods obsolete and prefer the use of the modern molecular approaches instead. However, this study surprisingly showed that the two approaches revealed distinctly different bacterial communities for each studied sample. This unexpected result consolidates that both techniques must not substitute one another, but should mutually complement each other, in order to gain a bacterial composition most close to reality.

\section{Competing interests}

The authors declare that they have no competing interests.

\section{Authors' contributions}

HA, MK, DM participated in sample collection and DGGE analysis. ND, NA, MK, SR contributed to molecular analysis. SR suggested the research problem and finalized the manuscript. All authors read and approved the manuscript.

\section{Acknowledgements}

This study has been supported by Kuwait University, research grant SL01/08.

Received: 17 March 2013 Accepted: 29 July 2013

Published: 1 August 2013

\section{References}

Al-Awadhi H, Al-Mailem D, Dashti N, Khanafer M, Radwan SS (2012) Indigenous hydrocarbon-utilizing bacterioflora in oil-polluted habitats in Kuwait, two decades after the greatest man-made oil-spill. Arch Microbiol 194:689-705 Al-Bader D, Kansour M, Rayan R, Radwan SS (2012) Biofilm comprising 354 phototrophic, diazotrophic, and hydrocarbon-utilizing bacteria: a promising 355 consortium in the bioremediation of aquatic hydrocarbon pollutants. Environ Sci Pollut Res (2013) 20:3252-3262

Al-Sarawi HA, Mahmoud HM, Radwan SS (2008) Pyruvate-utilizing bacteria as contributors to the food web in the Arabian Gulf. Mar Biol 154:337-381

Amann Rl, Ludwig W, Schleifer KH (1995) Phylogenetic identification and in situ detection of individual microbial cells without cultivation. Microbiol Rev 59:143-169

Arun K, Ashok M, Rajesh S (2011) Crude oil PAH constitution, degradation pathway and associated bioremediation microflora: an overview. Int J Environ Sci 1:1420-1439

Dahllöf I, Baillie H, Kjelleberg S (2000) rpoB-based microbial community analysis avoids limitations inherent in 165 rRNA gene intraspecies heterogeneity. Appl Environ Microbiol 66:3376-3380

Duarte CM, Vaqué D (1992) Scale dependence of bacterioplankton patchiness. Mar Ecol Prog Ser 84:95-100

El Fantroussi S, Verschuere L, Verstraete W, Top EM (1999) Effect of phenylurea herbicides on soil microbial communities estimated by analysis of $16 \mathrm{~S}$ rRNA gene fingerprints and community-level physiological profiles. Appl Environ Microbiol 65:982-988

Fuhrman JA, Davies AA (1997) Widespread Archaea and novel Bacteria from the deep sea as shown by 165 rRNA gene sequences. Mar Ecol Prog Ser 150:275-285

Head IM, Saunders JR, Pickup RW (1998) Microbial evolution, diversity, and ecology: a decade of ribosomal RNA analysis of uncultivated microorganisms. Microb Ecol 35:1-21

Jannasch HW, Jones GE (1959) Bacterial populations in sea water as determined by different methods of enumeration. Limnol Oceanogr 4:128-139

Jiménez N, Viñas M, Bayona JM, Albaiges J, Solanas AM (2007) The Prestige oil spill: bacterial community dynamics during a field biostimulation assay. Appl Microbiol Biotechnol 77:935-945

Kleinsteuber S, Riis V, Fetzer I, Harms H, Muller S (2006) Population Dynamics within a Microbial Consortium during Growth on Diesel Fuel in Saline Environments. Appl Envir Microbiol 72:3531-3542

Larentis M, Hoermann K, Lueders T (2009) Combined monitoring of aerobic and anaerobic contaminant degradation genes as a tool to assess NA. GOODWATER introductory winterschool, December 7-11. Helmholtz Zentrum München, (HMGU)

Long RA, Farooq A (2001) Microscale patchiness of bacterioplankton assemblage richness in seawater. Aquat Microb Ecol 26:103-113

Morawski B, Eaton RW, Rossiter JT, Guoping S, Griengl H, Ribbons DW (1997) 2-Naphthoate catabolic pathway in Burkholderia strain JT 1500. J Bacteriol 179:115-121

Muyzer G, Smalla K (1998) Application of denaturing gradient gel electrophoresis (DGGE) and temperature gradient gel electrophoresis (TGGE) in microbial ecology. Anton Leeuw Int J 73:127-141

Nielsen AT, Liu WT, Filipe C, Grady L, Molin S, Stahl DA (1999) Identification of a novel group of bacteria in sludge from a deteriorated biological phosphorus removal reactor. Appl Environ Microbiol 65:1251-1258

Nübel U, Garcia-Pichel F, Kuhl M, Muyzer G (1999) Quantifying microbial diversity: morphotypes, 16S rRNA genes, and carotenoids of oxygenic phototrophs in microbial mats. Appl Environ Microbiol 65:422-430

Polz MF, Cavanaugh CM (1998) Bias in template-to-product ratios in multitemplate PCR. Appl Environ Microbiol 64:3724-3730

Prabagaran SR, Manorama R, Delille D, Shivaji S (2007) Predominance of Roseobacter, Sulfitobacter, Glaciecola and Psychrobacter in seawater collected off Ushuaia, Argentina, sub-Antarctica. FEMS Microbiol Ecol 59:342-355

Rölleke SS, Gurtner C, Drewello U, Drewello R, Lubitz W, Weissmann R (1999) Analysis of bacterial communities on historical glass by denaturing gradient 
gel electrophoresis of PCR-amplified gene fragments coding for 165 rRNA. J Microbiol Methods 36:107-114

Scherr KE, Lundaa T, Klose V, Bochmann G, Loibner AP (2012) Changes in bacterial communities from anaerobic digesters during petroleum hydrocarbon degradation. J Biotechnol 157:564-572

Sekiguchi H, Tomioka N, Nakahara T, Uchiyama H (2001) A single band does not always represent single bacterial strains in denaturing gradient gel electrophoresis analysis. Biotechnol Lett 23:1205-1208

Seuront L, Gentilhomme V, Lagadeuc Y (2002) Small-scale nutrient patches in tidally mixed coastal waters. Mar Ecol Prog Ser 232:29-44

Seymour JR, Mitchell JG, Pearson L, Waters RL (2000) Heterogeneity in bacterioplankton abundance from 4.5 millimetre resolution sampling. Aquat Microb Ecol 22:143-153

Sievert S, Brinkhoff T, Muyzer G, Ziebis W, Kuever J (1999) Spatial heterogeneity of bacterial populations along an environmental gradient at a shallow submarine hydrothermal vent near Milos Island (Greece). Appl Environ Microbiol 65:3834-3842

Sipos R, Székely AJ, Palatinsky M, Révész S, Marialigeti K, Nikolausz M (2007) Effect of primer mismatch, annealing temperature and PCR cycle number on 165 rRNA gene-targetting bacterial community analysis. FEMS Microbiol Ecol 60:341-350

Teramoto M, Suzuki M, Okazaki F, Hatmanti A, Harayama S (2009) Oceanobacterrelated bacteria are important for the degradation of petroleum aliphatic hydrocarbons in the tropical marine environment. Microbiol 155:3362-3370

van Hannen EJ, Mooij W, van Agterveld MP, Gons HJ, Laanbroek HJ (1999a) Detritus-dependent development of the microbial community in an experimental system: qualitative analysis by denaturing gradient gel electrophoresis. Appl Environ Microbiol 65:2478-2484

van Hannen EJ, Zwart G, van Agterveld MP, Gons HJ, Ebert J, Laanbroek HJ (1999b) Changes in bacterial and eukaryotic community structure after mass lysis of filamentous cyanobacteria associated with viruses. Appl Environ Microbiol 65:795-801

Wan C, Du M, Lee DJ, Yang X, Ma W, Zheng L (2011) Electrokinetic remediation and microbial community shift of $\beta$-cyclodextrin-dissolved petroleum hydrocarbon-contaminated soil. Appl Microbiol Biotechnol 89:2019-2025

Wang YN, Cai H, Yu SL, Wang ZY, Liu J, Wu XL (2007) Halomonas gudaonensis sp. nov., isolated from a saline soil contaminated by crude oil. Int J Syst Evol Microbiol 57:911-915

Yakimov MM, Giuliano L, Denaro R, Crisafi E, Chernikova TN, Abraham WR, Luensdorf H, Timmis KN, Golyshin PN (2004) Thalassolituus oleivorans gen. nov., sp nov., a novel marine bacterium that obligately utilizes hydrocarbons. Int J Syst Evol Microbiol 54:141-148

Yakimov MM, Timmis KN, Golyshin PN (2007) Obligate oil-degrading marine bacteria. Curr Opin Biotech 18:257-266

Yergeau E, Lawrence JR, Sanschagrin S, Waiser MJ, Korber DR, Greer CW (2012) 458 Next-generation sequencing of microbial communities in the Athabasca 459 River and its tributaries in relation to oil sands mining activities. Appl Environ Microbiol (2012) 78:7626-7637

Zhu H, Singleton DR, Aitken MD (2010) Effects of nonionic surfactant addition on populations of polycyclic aromatic hydrocarbon-degrading bacteria in a bioreactor treating contaminated soil. Environ Sci Technol 44:7266-7271

doi:10.1186/2193-1801-2-369

Cite this article as: Al-Awadhi et al:: Bias problems in culture-

independent analysis of environmental bacterial communities: a representative study on hydrocarbonoclastic bacteria. SpringerPlus 2013 2:369.

\section{Submit your manuscript to a SpringerOpen ${ }^{\circ}$ journal and benefit from:}

- Convenient online submission

- Rigorous peer review

- Immediate publication on acceptance

- Open access: articles freely available online

- High visibility within the field

- Retaining the copyright to your article

Submit your next manuscript at $\gg$ springeropen.com 